Образование в документах. Информационный бюллетень. - 1999. - №5 (92). 4. Грива О. А. Толерантність як складова життєвої компетентності особистості / О.А. Грива // Науковий часопис Національного педагогічного університету ім. М.П.Драгоманова. - Серія 7: Релігієзнавство, культурологія, філософія. - 2005. - Вип. 6 (19). - С. 58-67. 5. Декларація принципів толерантності / [Електронний ресурс]. - Режим доступу: http://zakon2.rada.gov.ua/laws/ show/995_503 6. Довідник міжетнічної толерантності / упоряд. Н. Ю. Ротар; за ред. А. М. Круглашова. - Чернівці : Видавничий дім «Букрек», 2011. - 232 с. 7. Етносоціологія: терміни та поняття : [навч. посіб.]. - К. : Фенікс, 2003. - 234 с. 8. Закон України «Про освіту» / [Електронний ресурс]. - Режим доступу: Ошибка! Недопустимый объект гиперссылки.9. Міжетнічна інтеграція: постановка проблеми в українському контексті [Текст] : [навч. посіб.] / В. Б. Свтух, В. П. Трощинський, Л. О. Аза. - К. : ВПЦ «Київ. ун-т», 2003. - 58 с. 10. Кожухарь Г. С. Проблема толерантности в межличностном общении / Г.С. Кожухарь // Вопросы психологии. - 2006. - № 2. - С. 3 - 12. 11. Краткий психологический словарь / под ред. А. В. Петровского, М. Г. Ярошевского. - М. : Политиздат, 1985. - 431 с. 12. Толерантность в межкультурном диалоге. - М. : Институт этнологии и антропологии РАН, 2005. - 365 с. 13. Лебедева Н. М. Межкультурный диалог: проблемы этнокультурной компетентности / Н. М. Лебедева // Этнический фактор в многонациональном пограничном регионе. - Оренбург, 2007. - С. 6 - 29. 14. Словник іншомовних слів / за ред. О. С. Мельничука. - 2-е видання, випр. і доп. - К. : Головна редакція «Українська радянська енциклопедія» (УРЕ), 1985. - 966 с. 15. Формирование толерантной личности в полиэтнической образовательной бреде : [учебное пособие]. - М. : Педагогическое общество России, 2004. - 240 с.

УДК 378.147:54

E. В. Часова, кандидат хім. наук, доцент,

B. В. Івчук, кандидат біолог. наук, ст. викладач, ДВНЗ «Криворізький начіональний університет»

\title{
ПЕРСПЕКТИВИ ХІМІЧНОЇ ОСВІТИ В УНІВЕРСИТЕТАХ ТЕХНІЧНОГО ПРОФІЛЮ
}

Часова Е. В., Івчук В. В. Перспективи хімічної освіти в університетах технічного профілю.

У статті окреслено основні тенденції хімічної освіти в університетах технічного профілю. Висвітлено роль забезпечення якості вищої освіти як важливої умови інноваційного розвитку у професійно зорієнтованому навчанні.

Ключові слова: хімічна освіта, нехімічні спеціальності, технічні університети, форми навчального процесу, аксіологія.

Часова Э. В., Ивчук В. В. Перспективы химического образования в университетах технического профиля.

В статье приведены основные тенденции химического образования в университетах технического профиля. Показана роль обеспечения качества высшего образования как важное условие инновационного развития в профессионально ориентированном обучении.

Ключевые слова: химическое образование, нехимические специальности, технические университеты, формы учебного процесса, аксиология.

Chasova E. V., Ivchuk V. V. Perspectives of chemical education in universities of technical profile.

The article led the main trends of chemical education at the universities of technical profile. The role of quality assurance in higher education, as an essential condition for innovative development in the career-oriented education.

Key words: chemical education, non-chemical specialties, technical universities, the forms of the educational process, axiology.

Нині вітчизняна вища освіта стає все більш доступною. Вибір абітурієнта є однією 3 актуальних проблем. Головною перешкодою для багатьох абітурієнтів є те, що вища освіта може бути платною та зміни в характері взаємовідношень між професійними навчальними закладами і школами. Останнім часом окреслилася небажана тенденція 
зменшення обсягу годин на вивчення загальної хімії в школі. Підготовка абітурієнтів 3 хімії щороку погіршується. Але сучасні хімічні дослідження вийшли за межі природних речовин. Наступний етап науково-технічного прогресу - це залучення нанотехнологій та поява наноматеріалів, що зводить розміри технічних конструкцій до розмірів молекул, атомів $[1,7]$.

Meта статmi - проаналізувати перспективи хімічної освіти в університетах технічного профілю.

Сучасному інженеру-конструктору необхідно знати оптимальні параметри перебігу тих або інших хімічних перетворень, які лежать в основі технологічного процесу, розумітися у властивостях і якостях різних видів матеріалів, що $є$ неможливим без спеціальної хімічної підготовки [8].

Тому курс хімії для студентів нехімічних спеціальностей повинен бути достатньо широким та вагомим, щоб мати змогу сформувати цілісне уявлення про можливості хімії як науки, яка $\epsilon$ основою науково-технічного прогресу, для розуміння хімії у побуті, для розв'язання екологічних питань. Більш загальною метою вивчення хімії $\epsilon$ формування творчого хімічного мислення [5;9].

Водночас, процес навчання хімії у технічному ВНЗ є важкою справою. Чим вищий рівень інтелектуального розвитку абітурієнтів, чим вищий їхній базовий рівень знань, тим вищий і майбутній рівень освіти студентів. За даними міжнародних досліджень, абітурієнти в більшості випадків не вміють правильно прочитати хімічний текст, чітко відповісти на питання, інтерпретувати хімічну інформацію, використовувати практичні навички. Цей же факт підтверджує велика кількість студентів, які мають досить поверхові уявлення про такі важливі поняття хімії, як кількість речовини, молярна маса, молярний об’єм газу, постійна Авогадро, валентність, ступінь окиснення. Більшість не може написати найпростіших формул. Недостатність засвоєння шкільної теми «Розчини. Теорія електролітичної дисоціації» можна проілюструвати таким прикладом. У межах робочої навчальної програми студенти першого курсу більшості спеціальностей університету вивчають тему «Розчини електролітів». Важливість теми визначається тим, що розчини електролітів знаходять різноманітне застосування в технології отримання напівпровідників, в очищуванні речовин, роботі хімічних джерел струму, процесі травлення металів. Знання цієї теми $є$ основою для розуміння понять фізико-хімічних процесів, які відбуваються на межі розподілу фаз за участі заряджених часток, прогнозування здійснення окисно-відновних реакцій. Більшість зі студентів не може впоратись 3 елементарними практичними розрахунками основних характеристик розчинів електролітів, оскільки не розуміють, що таке електроліти, іони і як записується рівняння дисоціації. У зв'язку з великими прогалинами у шкільному рівні знань, викладання хімії в технічних вузах починається з основних понять та законів хімії [8].

Особливістю вивчення хімії у технічних ВНЗ є те, що цей процес має згорнутий характер. Значний обсяг теоретичного та фактологічного матеріалу необхідно вивчити за короткий час і за мінімальну кількість занять. Відсутність в абітурієнтів розуміння ролі хімічного знання в поясненні фізико-хімічних властивостей матеріалів створює психологічний бар'єр під час вивчення курсу хімії вищої школи. Окрім того, прослідковується тенденція останнього часу - студенти не мають елементарних навичок навчальної діяльності. Виникає проблема закріплення отриманих знань, оскільки не підкріплені вміннями і навичками знання швидко втрачаються [3; 4].

Для подолання вказаних проблем підвищення рівня знань 3 хімії для студентів нехімічних спеціальностей технічних університетів використовуються такі форми організації навчального процесу: лекції; практичні та лабораторні заняття; самостійна робота студентів; контроль знань студентів [2].

Інформатизація суспільства пов'язана 3 інформатизацією освіти. Проведення сучасної лекції потребує використання мультимедійних технологій. Досвід такої організації лекційної форми навчання показує, що крім більшої наочності матеріалу, який 
викладається, зростає активність спілкування лектора 3 аудиторією, більш чітко виявляється зворотній зв'язок. Студенти залучаються до проблеми матеріалу, що викладається, шляхом постановки питань і подальшим підтвердженням відповідей на іспиті. Окрім того, лектор постійно стежить за аудиторією, що дисциплінує слухачів, вимагає їх працювати.

Найважливішу роль у виробленні навичок і вмінь застосування отриманих знань відіграють практичні заняття, які спрямовано на закріплення лекційного матеріалу і вирішення практичних задач, коли потрібне знання законів хімії та властивостей окремих речовин. Матеріал для практичних занять добирається відповідно до напрямку спеціальності, що зміцнює міжпредметні зв'язки. Студенти повинні постійно відчувати ускладнення завдань, які вони виконують, напругу творчої роботи.

Внесок лабораторних занять у вивчення хімії досить вагомий. Тому особливо важлива правильна організація пізнавального процесу - проведення і спостереження студентами хімічного експерименту. Більшість лабораторних занять повинна проводитись у формі дослідницьких робіт, що стимулює студентів до набуття знань і формує навички науководослідницької роботи.

У процесі навчання студентів повинні застосовуватись кілька видів самостійної роботи: самостійна робота на практичному й лабораторному заняттях і позааудиторна самостійна робота. Оскільки нині близько половини відведених на вивчення дисципліни годин за навчальним планом, сплановано на самостійну позааудиторну роботу студентів, виникає потреба в розробленні спеціальних посібників і контрольних завдань. Самостійна робота студентів органічно доповнює всі інші організаційні форми навчального процесу, а за умови заочної форми навчання - стає провідною. При цьому досить важливим завданням є забезпечення засобами навчання.

Контроль знань студентів у процесі навчання має кілька функцій: перевіряючу, навчальну, виховну. На лекційних, практичних, лабораторних заняттях контроль здійснюється за рахунок прямого та зворотного зв'язку «викладач-студент». Така форма контролю дозволяє викладачу корегувати виклад матеріалу, загострюючи увагу на недостатньо засвоєних поняттях та розділах. Для виявлення глибини та якості засвоєння матеріалу, що вивчається, можливе застосування різних видів контролю: контрольна робота за вивченим розділом; захист лабораторних робіт; реферати; доповіді й олімпіади; завдання для самоконтролю студентів; залік по завершенню вивчення курсу; іспит. Контроль знань студентів здійснюється за білетами або за тестовими контрольними завданнями. Контроль знань, умінь і навичок допомагає виявити прогалини у знаннях студентів, чинить стимулювальний вплив, формує творче ставлення до предмету та бажання розвинути свої здібності. Контрольні заходи встановлюють зворотній зв'язок від студента до викладача, надають змогу викладачу керувати навчальним процесом, індивідуально враховувати результати кожного студента під час планування та подальшої організації його навчання.

Викладання хімічних дисциплін неможливо здійснювати без засобів навчання, а саме: навчально-методичних посібників; технічних засобів навчання.

Аналіз статистичних даних дозволяє зробити такі висновки. У сучасних реаліях в освітньому середовищі технічного ВНЗ виокремилися три стійкі тенденції: зменшення рівня знань шкільного курсу хімії абітурієнтів; тенденція різкого зниження активу вмінь і навичок навчальної діяльності; тенденція зниження мотивації до вивчення хімії. Вивчення причин, що впливають на успішність 3 хімічних дисциплін, дозволяє відпрацювати прийоми та методи навчання, провести коригувальні дії. Технологія вивчення хімії в технічному ВНЗ будується за принципом адаптованості рівня інформації, що пропонується з предмета, відповідному рівню аудиторії. Викладання хімії в технічному університеті переслідує мету не стільки виклад самої науки, але, як необхідність, аксіологічного заломлення хімічних знань крізь призму свідомості майбутніх інженерів [6]. 
Зацікавити студента, долаючи характерне для технічних ВНЗ скептичне ставлення слухачів до хімії, залучити його до процесу навчання, зробити предмет вивчення зрозумілим i, як результат, навчити - це основа аксіологічної задачі віднайдення способів і методів викладання навчального матеріалу з предмета. Із цієї причини добір лекційного матеріалу, матеріалу в навчальних посібниках відбувається, виходячи 3 цінності, важливості і значущості знань із хімії для майбутньої діяльності інженера, а рівень і стиль викладання сприяє аксіологічній мотивації вивчення хімії. Тому в низці випадків під час компонування деяких розділів хімії робиться вибір на користь аксіологічно доступного розуміння матеріалу, який викладається [4].

Наведені вище підходи значною мірою підвищують мотивацію у вивченні дисципліни, позитивно впливають на зростання успішності з предмета, i дозволяють досягнути головної мети - навчити студентів вчитися та забезпечити достатній рівень знань, що гарантує подальше вивчення інших дисциплін у технічному ВНЗ.

\section{Література}

1. Гран Р. Й. Реформы образования и старшая школа / Р.Й. Гран. - М. : Недра, 2003. - 154 с. 2. Днепров Э. Д. Образовательный стандарт в контексте обновления содержания образования /Э. Д. Днепров. - М. : Институт новых образовательных систем, 2002. - 26 с. 3. Забезпечення якості вищої освіти - важлива умова інноваційного розвитку держави і суспільства // Інформаційно-аналітичні матеріали до засідання підсумкової колегії Міністерства освіти і науки, 1-2 березня 2007 року. - Київ, 2007. - 96 с. 4. Коржуев А. В. Традиции и инновации в высшем профессиональном образовании / А. В. Коржуев, В. А. Попков. - М. : Изд-во Моск. ун-та, 2003. 300 с. 5. Кузьменко Н. Е. О некоторых проблемах реформирования общего и высшего химического образования в России / Н. Е. Кузьменко, О. Н. Рыжова, В. В. Лунин. // Современные тенденции развития химического образования. - Кишинэу: Univers Pedagogic, 2005. - 136 с. 6. Макарова Л. Л. Совершенствование химического образования как важная составляющая концепции модернизации высшего образования / Л. Л. Макарова, О. А. Овечкина. // Вестник Удмуртского университета, серия «Психология и педагогика». - 2008. - № 9. - С. 53-58. 7. Сергеев Г. Б. Нанохимия / Г. Б. Сергеев. - М. : Изд-во Моск. ун-та, 2003. - 288 с. 8. Deters K. M. What Should We Teach in High School Chemistry? / K. M. Deters // J. Chem. Educ., 2003, v. 80, № 10. - P. 1153-1555. 9. Mason D. S. What is Chemical Education? / D. S. Mason // J. Chem. Educ., 2003, v. 80 , № 5. - P. 465 .

УДК [377:61]:37.032

I. I. Черемісова, аспірант,

Харківський наиіональний педагогічний університет імені Г. С. Сковороди

\section{ОРГАНІЗОВАНІСТЬ ЯК ОДНА 3 ГОЛОВНИХ ПРОФЕСІЙНО ВАЖЛИВИХ ЯКОСТЕЙ МЕДИЧНОГО ПРАЦІВНИКА}

Черемісова I. І. Організованість як одна 3 головних професійно важливих якостей медичного працівника.

У статі розглянуто професійно важливі якості медичного працівника, визначено ці якості. Розкрито суть і зміст професійних якостей медичного працівника.

Ключові слова: студент, професійні якості медичного працівника, самостійність, організованість.

Черемисова И. И. Организованность как одна из главных профессионально важных качеств медицинского работника.

В статье рассмотрены профессионально важные качества медицинского работника, определены эти качества. Раскрыты суть и содержание профессиональных качеств медицинского работника.

Ключевые слова: студент, профессиональные качества медицинского работника, самостоятельность, организованность. 